\title{
Ocorrência do carvão da cana-de-açúcar nos Estados do Piauí e Maranhão
}

\author{
Gilson Soares da Silva ${ }^{1}$, Francisco de Alcântara Neto ${ }^{2}$, Raycenne Rosa Leite ${ }^{1}$, Keyla Cosme da Silva ${ }^{2}$, Marinete \\ Martins de Sousa Monteiro ${ }^{2}$, Marcos André Melo de Oliveira ${ }^{3}$
}

\begin{abstract}
${ }^{1}$ Departamento de Fitotecnia e Fitossanidade, UEMA, 65001-970 São Luís - MA. ${ }^{2}$ Departamento de Fitotecnia, UFPI, 64049-550 Teresina - PI. ${ }^{3}$ Aged.São João dos Patos, MA.

Autor para correspondência: Gilson Soares da Silva (gilson_soares@uol.com.br)

Data de chegada: 13/11/2013. Aceito para publicação em: 09/05/2014.
\end{abstract}

$10.1590 / 0100-5405 / 1947$

O carvão da cana-de-açúcar, Sporisorium scitaminae (sin.:Ustilago scitaminae), destaca-se como uma das mais importantes doenças da cultura, podendo causar perdas de $100 \%$ em áreas com variedades suscetíveis. Descrita no Brasil em 1946, no Estado de São Paulo, é atualmente encontrada em diversas regiões do país especialmente no Sul e Sudeste. No Nordeste, a despeito das condições favoráveis à sua ocorrência, só em 1985 foi registrado no município de Cascavel no Estado do Ceará. Em setembro e em novembro de 2013, foram coletadas amostras de cana-de-açúcar, variedades CVNE 077752 e RB 92579, cultivadas no município de União, PI e em variedade não identificada em São João dos Patos, MA, apresentando sintomas típicos do carvão: plantas raquíticas, colmos finos e a presença da estrutura característica da doença, o chicote, transformação do meristema apical induzida pelo fungo, medindo aproximadamente $1 \mathrm{~m}$ de comprimento (Fig. $1 \mathrm{~A}$ ). O exame microscópico desses sinais revelou a presença de teliósporos unicelulares, escuros, medindo 5,3 a 6,8 $\mu$ m de diâmetro, com pontuações na superfície (Fig. 1 B). Essas característica permitiram identificar o patógeno como Sporisorium scitaminae, de acordo com a literatura especializada. Para a confirmação da etiologia da doença, mudas de cana-de-açúcar 'RB 92579', obtidas por meio de toletes cultivados em vasos, contendo solo autoclavado, foram inoculadas com uma suspensão de teliósporos, na concentração de $2 \times 10^{5}$ unidades $/ \mathrm{mL}$ e, em seguida, mantidas em câmara úmida por $48 \mathrm{~h}$. Após esse período, as plantas foram deixadas em condições de casa de vegetação. Vinte e dois dias após a inoculação, as plantas exibiram o chicote característico da doença (Fig. 1 C). Lâminas preparadas com material retirado desses chicotes confirmaram a presença de teliósporos com as mesmas características do material inicialmente examinado. A área cultivada com cana-de-açúcar no Estado do Piauí é de aproximadamente 18000 ha, distribuídos nos municípios de Teresina, União e José de Freitas. No Maranhão, a cana-de-açúcar ocupa 42000 ha, distribuídos principalmente nos municípios de Fortaleza dos Nogueiras, São João dos Patos e Sucupira, compreendendo desde pequenos plantios destinados à produção de aguardente até lavouras extensivas voltadas para a produção de álcool. A ocorrência do carvão deve ser vista como um fator de risco à produção de cana-de-açúcar, especialmente se variedades suscetíveis forem cultivadas. Medidas que visem evitar a disseminação do carvão para outras regiões do estado devem ser implementadas já. Portanto, o plantio de variedades resistentes ao carvão adaptadas às condições locais, é condição essencial para o sucesso da cultura canavieira naqueles estados.
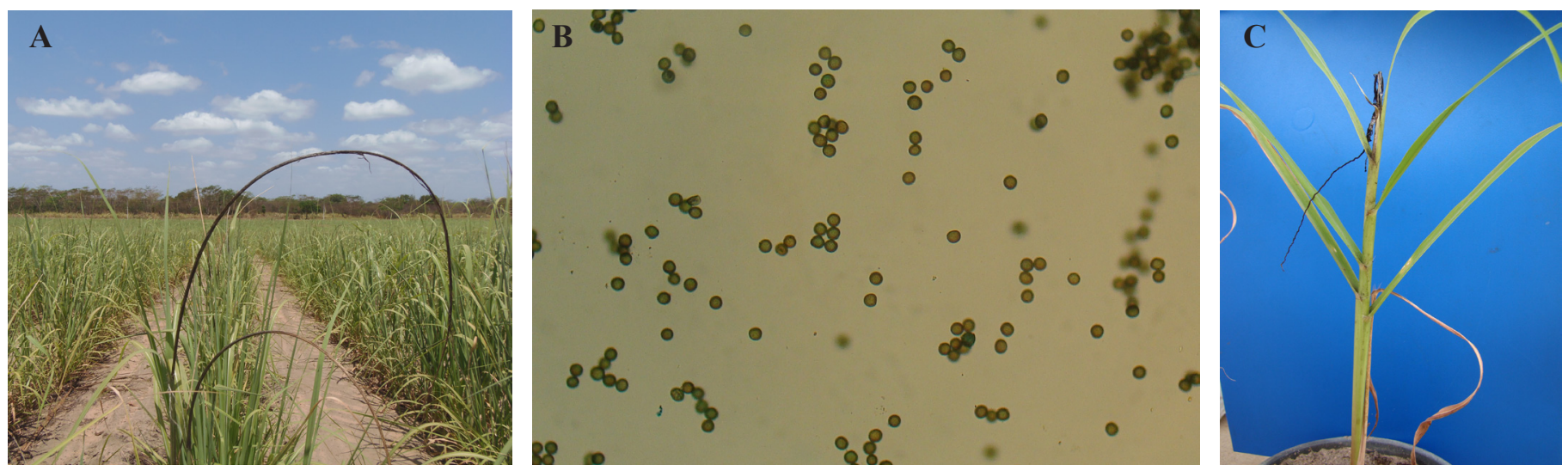

Figura 1. A - Chicote, sintoma característico do carvão; B - Teliósporos de Sporisorium scitamineum. C- muda inoculada, apresentando o chicote característico. 